\title{
RESPONSE
}

\section{John Irwin and the Convict Criminology Code Katherine Irwin}

$\mathrm{T}$ his issue of the Journal of Prisoners on Prisons (JPP) is dedicated, in part, to my father John Irwin, who was many things to many people. To some, he was the original felonious criminologist, a member of the Prisoners' Union, and the founder of Project Rebound, a program to turn former prisoners into college students. To others, my father was a prison scholar, with several seminal books to his name. And to Convict Criminologists and convicts, he was a talkative and interested guy who felt more comfortable circulating with outlaws than with straight folk. As Dad's daughter, it is an honor to respond to this issue of JPP in the spirit of my father's life and work.

As indicated by all of the manuscripts in this edition, Convict Criminology (CC) research offers several insightful contributions to the literature on punishment with the potential to correct the many misconceptions about convicts and imprisonment. Despite my academic support for the $\mathrm{CC}$ work and my excitement about the future of $\mathrm{CC}$ scholarship, my reaction to the achievements in this volume is personal. In fact, I see several moral threads that tie my father's most closely held beliefs to the $\mathrm{CC}$ tradition. After serving a five-year sentence for armed robbery, Dad organized his life around overcoming the degradation of prison on an individual and collective level. Moreover, Dad's agenda as a scholar, activist, and father was dedicated to clearly articulating a path away from the indignities of incarceration and towards a consequential life. It is not surprising then that I should read these fine manuscripts by other CC scholars and recognize the lessons that many of us learned from John Irwin. In the following, I outline a few of Dad's many instructions - or as his children refer to them, Dad's "lectures" - about how to live a useful and meaningful life.

\section{BE A HUMANITARIAN}

In his writing and talks, my father communicated a humanitarian message succinctly and clearly. What most criminologists did not, and still often do not realize, is that convicts are not psychologically damaged, emotionally sick and dangerous predators. They are human beings. While simple, this insight is profoundly instructive. When Dad started writing about prison in 
the late 1960s and 1970s, he dedicated his work to the "more than 200,000 convicts presently 'doing time' in the United States". Not surprisingly, scholars who were worried about the treatment of prisoners during this period also comprised a minority group. Today there are more than two million convicts "doing time" and, consequently, prison has become a fashionable topic among criminologists. Being a humanitarian means caring about prison as a central moral concern regardless of whether two, two hundred thousand or two million people are incarcerated.

My father argued that prison is a problematic institution deserving critical attention because imprisonment is a dehumanizing experience not only for prisoners, but also for their families, friends and communities. Here, the humanitarianism of CC scholars comes to the fore in the idea that our lives are inextricably intertwined with others. Therefore, it is more than just the individual prisoner who serves time. His or her children, partner, parents, neighbors and many others are all variously doing their own time as well.

Dad believed that solutions to the problems of prison were also based in humanist principles, including interconnection and mutual respect. In Project Rebound, my father supported the "each one teach one" model of mentorship in which each ex-convict college student can be a resource for others who are re-entering. Dad's collectivist approach, however, went deeper than mentorship or organizing a social movement and, instead, cut to the core of his effervescent personality and lifestyle. My father and my stepmother Marsha loved parties, conversation, and celebrations. As a result, the family home was a central location for gatherings of all kinds, including meetings, dinner parties, dance parties, football parties, and regular Friday night gettogethers that included family, students, friends, colleagues, ex-convicts, local activists, and Project Rebound members. A good measure of laugher, discussion, and storytelling helped to grease the wheels of camaraderie and mutual trust among this diverse collection of collaborators.

Dad's social ease did not diminish with age. Up until the last few weeks of his life, he regularly visited local prisons to hang out with new and old friends. On occasion, one of my father's friends would be released, and Dad was often there to help in the transition by locating jobs and places to live, as well as introducing these ex-cons to his circle of friends and colleagues. This goes beyond mentorship, entering the realm of companionship and connection that Dad believed was necessary to overcome prisonization. 
It is not surprising to me, therefore, that the $\mathrm{CC}$ movement is more than a research tradition. It is also a support group. There is great power in a collective, and my father would be the first to advocate that each of us sustain an intellectual community by reaching out to like-minded people on the other side of prison walls and the academy. Although the criminal justice system often prohibits prisoner organizations, and connections between and among ex-cons, convicts are certainly not the only individuals dedicated to combating the negative effects of incarceration. In the 1970s, Dad and other prisoners' rights activists acknowledged the contributions of lawyers, students, researchers, and religious leaders. Dad would be the first person to advocate for those who are re-entering to make connections with justice advocates, concerned individuals and other sympathetic people within their communities. Moreover, as the $\mathrm{CC}$ community illustrates, our everyday lives, thoughts and work are richer, more rewarding, and certainly more plentiful when we nurture a collection of people who are dedicated to the same goals.

\section{BE A ROGUE}

Believing that the only occupation appropriate for ex-cons involved manual labor, members of the California Board of Parole consistently encouraged my father to learn a trade while in prison and give up his dream of going to college. Being a bit of a rogue, my father usually did not follow the advice of those in the "establishment" and he certainly did not concern himself with what others thought about him. He was driven by his own moral proscriptions and, thus, he ignored the Parole Board's advice. Upon release he enrolled in college and later in a $\mathrm{PhD}$ program. Even in the late 1950 s and 1960s, when the U.S. prison population was relatively small, he knew that he would encounter considerable derision, and he was prepared to forge new and unpopular pathways. For criminologists and those exiting prison, Dad's tradition of being a bit of a rogue exemplifies how individuals can buck the current system and speak out or write against the status quo.

Despite Dad's habit of saying and doing unpopular things, he acknowledged that it was much harder to be a rogue today than it was in the 1960s and 1970s - a time when there was a certain amount of tolerance for social movements and rule breakers. Today, convicts are one of the most feared and hated groups in society, leading my father to argue that convicts are treated as 
"whipping dogs for others' sadistic and psychopathic hatred". The common condemnation of convicts means that being a rogue might not be an option for those who fear for their survival, inside and outside of prison.

Given the contemporary climate, the $\mathrm{CC}$ movement has more than just the potential to dramatically change prison scholarship - it is also instrumental for millions who have re-entered society. For example, last year, I had five students separately tell me that they had criminal justice records and none wanted the rest of the class to know. In addition, another ten students discussed having family members who had been in prison. America's incarceration binge has brought prison closer to our homes and classrooms, and I am so thankful to have a large collection of CC scholarship to prove that each of these apprehensive students is not alone. This would not be possible if previous CC scholars had listened to the voice of the establishment by avoiding college and had remained quiet about their experiences. For their courage, I am most thankful.

\section{BE RESPONSIBLE}

My father consistently espoused the belief that we all have to accept responsibility for our mistakes. He understood that humans make many mistakes, some of which could have been avoided with careful consideration and good decision-making skills - but not all. As an example, in the early years of Dad's criminal justice work, he and his colleagues were convinced that the discretionary powers of judges was to blame for punitive sentencing decisions in the 1970s, and they vociferously campaigned against nonequitable, arbitrary and indeterminate sentencing. Twenty years later, Dad and many others learned that with determinate sentencing after the 1980s came more and harsher punishments. He and his colleagues quickly spoke out about the downsides of their early policy stance and revised their recommendations.

Being responsible also means that my father encouraged others to consult with as many individuals as possible before advocating for any particular policy. Although he had experienced prison first hand, Dad never felt comfortable relying exclusively on his personal biography to make sense of criminal justice theory, policy or practice. In fact, $\mathrm{CC}$ scholars and prisoners' rights advocates have embraced the idea that including a diverse cross-section of voices in policymaking can only lead to better policies and practices. In the 1970 s, for example, one of the founding principles 
of the Prisoners' Union was that individuals who are serving time should have a say in the practices that affect them, including visitation, research on prisoners, grievance systems, pay for prison labor, access to adequate health care and access to meaningful programming, to name just a few. This just seemed like sane policymaking.

Being responsible by considering as many viewpoints as possible also points to future directions for the $\mathrm{CC}$ movement. The $\mathrm{CC}$ papers in this volume include some voices but not others. I am especially eager to hear more from women and juveniles, whose experiences have been a cornerstone of prisoners' rights advocacy in the past. Also, I am eager for Latinos, Asians, and indigenous people of America, the Pacific Islands, and the Caribbean to offer their narratives to the expanding CC story. I have no doubt that as this tradition continues Convict Criminology will be able to draw more diverse voices and perspectives into the fold.

\section{ABOUT THE AUTHOR}

Katherine Irwin, $\mathrm{PhD}$, is an Associate Professor of Sociology at the University of Hawaii, Manoa. She has conducted research in the areas of youth culture, women and drug use, youth violence, girls in the juvenile justice system, and youth violence prevention programs. Her work has been published in a number of journals such as Contemporary Drug Problems, Critical Criminology, Qualitative Sociology, Sociology Compass, Sociological Spectrum, Symbolic Interaction, Youth and Society, and Youth Violence and Juvenile Justice, among others. 